\title{
Comparative Analysis of Regional Development of Northern Territories
}

\author{
Andrey G. Shelomentsev ${ }^{1,2}$, Olga A. Kozlova ${ }^{1,2}$, Zhanna A. Mingaleva ${ }^{3}$, Yelena B. Bedrina ${ }^{1}$ \& Tatyana V. \\ Terentyeva ${ }^{2}$ \\ ${ }^{1}$ Ural Branch of the Russian Academy of Sciences, Yekaterinburg, Russia \\ ${ }^{2}$ Vladivostok State University of Economics and Service, Vladivostok, Russia \\ ${ }^{3}$ Perm National Research Polytechnic University, Perm, Russia \\ Correspondence: Andrey G. Shelomentsev, Ural Branch of the Russian Academy of Sciences, 29, Moskovskaya \\ st., Yekaterinburg, 620014, Russia.
}

Received: December 20, 2014

Accepted: February 20, 2015 Online Published: May 22, 2015

doi:10.5539/ass.v11n14p349

URL: http://dx.doi.org/10.5539/ass.v11n14p349

\begin{abstract}
The analysis of northern regional development on the basis of the synthesis of comparative research and historical method is carried out in the article. The study of social and economic system enables us to understand better the roles of factors and methods of the governmental control of regional development as well as their position in social and economic and geopolitical aspect.

The northern regions of such countries as Russia (Kamchatka Krai), Canada (Yukon), the USA (Alaska), Japan (Hokkaido), and Iceland and Greenland were chosen as an object of research. All these regions play a strategically significant role in social and economic development of own countries and have climatic similarities.

The determination of common features of regional social and economic modeling makes it possible to compare the development of regions, having the same climatic, economic and geopolitical conditions but different levels of economic activity

There is the statistics generalization, characterizing various activities of regions, including structure of economy, its infrastructure supply, demographical situation, and financial sphere, that enables to see the features of national models of regional economies development. It is also proved that ignoring the actual connection between regional system elements and external and internal factors leads to loosing historical and social and economic basis in research.
\end{abstract}

Keywords: comparative analysis, regional system elements interaction, regional development models, conditions and factors of development, comparative assessment

\section{Introduction}

The analysis of policy of Russian Federation regions has shown that the climatic, economic, social, ecological, ethnic and other peculiarities ought to be taken into consideration, as well as negative and positive experiences of use of the different social and economic regional development stimulation.

The approaches to policy design, being used in the beginning of the twentieth first century played a great positive role, which enabled to understand long-term directions, tools and regional development institutions. According to the experience the documents had been formally drafted in a half of the regions.

The meaningful ten-year experience in regional strategic management, interaction between authorities, business interaction, population interaction, and public organizations interaction has helped to create new mechanisms of the conciliation of the interests. At the same time the object of strategic management has been changing itself - it has become more economically and socially dynamic. The changings have influenced the external environmentthe regions have cooperated both with the regions within and outside the country more actively. Thus, the scientific problem is that widely used strategic planning methodology has already fallen behind actual level of social and economic regional development of Russia and needs innovations, which let consider fresh knowledge and gained foreign and Russian experiences in regional development. 


\section{Theoretical and Methodological Background}

The questions of development of northern regions have been studied in researches of R. Bone (1992), A. V. Belikovich (1995), A. A. Kharevskiy (2001), G. A. Agranat (2003), E. R. Pullman, M. T. Jorgenson, Y. Shur (2007), V. B. Vereshchagina (2011), K. Grandmont, J. A. Cardille, D. Fortier, T. Gibryen (2012), H. H. Scheel (2012), O. A. Kozlova, and A. V. Karmakulova (2013).

The method of research. The main method of research is the comparative analysis. It is based on comparing differences, backgrounds, and natures of social and economic regional systems development and enables to avoid general summary regarding different national economy models. Hokkaido (Japan), Kamchatka Krai (Russia), Iceland and Greenland, Spitsbergen (Norway), Alaska (the USA), the Aleutian Islands (the USA), Yukon (Canada) were chosen as an object of comparative analysis. According to the authors' opinions successful foreign social and economic development models have their own specifics and cannot be used in Russia without adaptation.

The comparative analysis of social and economic development of regions with similar geographical, geological and climatic conditions made it possible to define effective instruments, factors and resources able to provide dynamic development of region economies. The analysis of state regulation instruments provides a deeper understanding of the role of the state regulation in the enhancing the effectiveness of regional development.

The comparative analysis method is supposed to be very perspective and useful to assess the directions of regional development.

In the research statistic data of Russia, statistic data of Iceland, Greenland, the USA, Canada, Japan, the current social and economic development strategies and programs, the official statistics of Kamchatska Krai, Khabarovsk Krai, Magadan and Sakhalin Oblasts, Chukotka Autonomous Area, Republic of Sakha (Yakutia) and other data have been used.

\section{The Results}

\subsection{The Comparative Assessments of Regional Development Models}

The key elements, characterizing regional development model have been sorted out. These are macroeconomic situation, sectoral structure of regional economy, infrastructure supply, and demographical processes, institutional environment, financial situation. All together they make up the basis and reflect the specifics of the functioning of the particular regional economy.

Hokkaido prefecture has the highest GDP as it has the biggest number of population among the considered regions. However, Yukon and Alaska have higher GDP per capita. The high GDP in these countries can be explained by the importance of mining industry, which strikes gold, silver, diamonds. Iceland, where a diversify sector of manufacturing industry prevails, has a medium GDP. The regions, Greenland and Hokkaido, specializing on seafood industry, have lower GDP.

The tertiary economic sector of the northern states is developed due to specifics of the economic conditions and socially orientated policy of these states. Expenditure on healthcare in Iceland makes up 9,1\% of GDP(Health expenditure, 2012), while total expenditure on healthcare, education and social services in Kamchatka is $13 \%$ of GRP (The structure of the gross, 2012). In Yukon it is 12,4\% of DRP (Gross Domestic Product, 2012), in Alaska it is $6,4 \%$ of GRP (U.S. Economic Accounts, 2012).

There is a high amount of expenditure on public administration in the regions studied. The reason for this is the special regulations, which are introduced due to the high ecological standards, and the necessity in military protection.

The unique climatic conditions, the surface of the territory, water resources, and volcanic activity with state development policy provide with tourists. Due to this the great amount of services falls on tourism sector. Regional tourism is considered to be successful. The tourism sector of the northern countries has definite specifics and represented by eco and extreme tourism, mountaineering, sky resorts, sport fishing and hunting.

\subsection{The Comparative Assessments of Regional Economic Structure}

Comparative analysis has showed sectoral structure similarity between neighboring countries. European countries, Greenland and Iceland, as well as the states of North America, have similar sectoral structure.

The fisheries is the leading strategic sector of economy for majority of regions considered, and other sectors such as service, shipbuilding, fish processing and so on are dependent. The fisheries contribution in the GRP of Kamchatka Krai is $17,4 \%$, Fisheries contribution in the GDP of Iceland is $7,1 \%$, Greenland $-8,3 \%$. The 
Aleutian Islands are also specialized on seafood. The economy of Greenland depends on fish export and fishing. The fifth part of Greenland budget goes to fisheries development (trawler building, fishery re-equipment) (Statistics Greenland, 2014). Fishing and fish processing is the important sector in Iceland, which provides $12 \%$ of population with workplaces and makes up 70\% of export (Iceland's economy, 2014). There is the great number of factories, farming salmon in Hokkaido.

The fisheries contribution of Kamchatka in catches of Far East is 36, $0 \%$, in catches of Russia is more than $24,0 \%$. Moreover, the fishery in Kamchatka is a part of the fishing complex, which accounts for more than 50,0\% of industrial production volume and about $86,0 \%$ of krai export. Regarding agriculture Iceland has an experience of geothermal water hothouse production development. Nowadays the deer-raising program is being realized in Kamchatka. There has been focused deer farming development in Ireland, Greenland, North America. The traditional partridge-shooting in Greenland and bear hunting in the north and in the east occur (Vozgrin, 1984). Hokkaido is located in the temperate zone and specialized on agricultural production. Hokkaido is the main agricultural products supplier in Japan. Agricultural products contribution in GRP makes up 3,5\% in Kamchatka, while crop products fulfill the needs of population and animal products do it partly (Socio-economic status, 2012).

Alaska, North Canada, Spitsbergen have got raw material bases, developing natural resources. Greenland, Iceland, Kamchatka consider their raw material bases as a development potential. There is traditional offshore hydrocarbons production in Alaska. $25 \%$ of the US oil is produced there. Moreover, Alaska holds second place in The USA (after Nevada) in gold mining, it produces about $8 \%$ of silver and so on (Alaska, 2013). The essential part in mining industry plays diamonds mining. The foreign companies, which make concession, take an active part in striking in Greenland. According to the legislation, they pay the government an interest after they have covered prime investments. There are several silver and gold, silver, lead and zinc mines in Yukon. The diamonds sector developing has influenced the related sectors development, trade and infrastructure in the North-West Canada. Iceland, where mining industry has been represented by a little volume of brown coal, pumice and Iceland spar, has started to develop oil field of Iceland continental shelf and produce argil. Mining industry in Hokkaido also plays a little part. Mining industry is represented by coal production ( $1 / 4$ of Japanize coal production). On the island there is also iron ore mining and oil production (Japan, 2014). Coal production is also essential in Spitsbergen. Coal is exported to Germany. The mining industry development can have some negative ecological effects and aggravate situation for local inhabitants' craft. However, providing the conciliation of the interests mining industry developing can lead to gaining economic profits for both sides as it was in Alaska (The Mining Industry, 2014).

\subsection{The Comparative Assessments of Manufacturing Activity}

Manufacturing activity is developed in Iceland, Hokkaido prefecture, Kamchatka Krai and makes up 14,2\%, 18,2\% и $8,5 \%$ of GDP (GRP) correspondingly (METI, 2014). The primary sector of economy is the basis of manufacturing activity development in these regions. Thus, food industry, which makes up one third of total cost of products on the island, is developed on the basis of fisheries and agricultural industry in Hokkaido. Due to forestry there are forest processing and cellulose products. The industries such as metalworking, engineering, electrical engineering, stone working are developed (Hokkaido, 2009). The production of Iceland is also connected with fish processing (drying, frosting, fish fillet and flour making). There are shipyards and ship repair facilities, servicing fishing fleet. Metallurgy and chemical manufacturing are developed. There is a cement plant, a factory, producing marine water salt, a ferrosilicon factory. Electrical equipment, furniture, clothes, woolen goods, footwear, metal goods, construction materials are produced. Power-consuming industries such as aluminum plant (American Century Aluminum, 2014), a plant, producing nitrogenous fertilizers are being set up (Enterprises Iceland, 2014). Processing industry is less developed in Greenland than in Hokkaido and Ireland. Kamchatka food industry is represented by 190 year round or seasonal production cycle fish processing plants, 17 of them are canned fish factories and their contribution in the krai industrial production is $52,4 \%$ in 2012 . Ship repair, containers production, fishing net production, construction materials production are also being realized in Kamchatka (Socio-economic status, 2012).

Energy infrastructure development of the northern regions is the key factor of their development. Thus, the current power engineering of Iceland is called "green" i.e. ecologically clean, because energy is generated through renewable energy sources. Due to the glaciers and the waters flown water-power engineering makes up $75 \%$, the geothermal sources produce $25 \%$ of energy while the traditional hydrocarbon accounts for only $0,5 \%$ (Population of Svalbard, 2013). The geothermal sources are considered to be essential for power engineering in the future. Nowadays the projects to use geothermal energy in aluminum industry are being developed. In Iceland a hydrogen fuel transition program has been adopted. The energy sector of Greenland is characterized by 
the potential of various energy resources. The geological prospecting of island and nearby territories has brought to new energy resources fields developing. The alternative fuels projects are introduced in Greenland. For instance, in Uummannaq 13\% of energy, used for maintenance, is obtained from biofuel (Belikovich, 1995).

In Northern Canada water power stations are mainly used. A great number of the out-of-network electric power stations is the particular quality of local energy sector. The usage of diesel and oil products brings some ecological, economic, social problems. In Canada the special program - "ECOENERGY for Aboriginaland Northern Communities Program" (EcoENERGY, 2012) has been developed. It aims to use clear renewable sources such as solar, wind, volcanic activity for generating electric power in the Northern communities. Canada is building several geothermal fuel power stations that are $20 \mathrm{MW}$ in capacity.

Alaska possesses a great amount of not enough used energy resources such as oil, gas, coal and also possesses some undeveloped geothermal resources on the Aleutian Islands. The great amount of electricity is generated from coal, natural gas or diesel in Alaska. The hydropower engineering is developed. The state policy is aimed at developing clean renewable energy resources and stimulates developing of wind and solar power engineering.

Hokkaido takes the eighth place in Japanize rating of electricity consuming and possesses developed energy sector. The climatic island conditions have predetermined the broad choice of various clean energy sources such as wind, solar, snow, ice etc. The open relief form and low estate prices have made Hokkaido an attractive place for developing renewable power. Hokkaido and Kamchatka resemble regarding climatic conditions, which means that the experience of Hokkaido can be drawn on.

\subsection{The Comparative Assessments of Transport Systems}

The Arctic countries and Russia transport systems are mainly focused on exporting natural resources and importing food, industrial goods, and consumer goods. Transport systems are also focused on servicing military facilities in the Arctic region. The arctic shipping is mainly represented by icebreaker transports. The USA and Canadian Coast Guard icebreakers are funded by the states, while the civil icebreakers are owned by private companies. All types of icebreakers in Greenland are owned by the government. Marine infrastructure plays an essential role for the countries studied (except Northern Canada) because of their geographical position. There is almost only sea freight in Hokkaido (Hokkaido, 2009). There are 29 seaports in Iceland and modern Greenland (Lonak, 2014). There are also small loading berths in some settlements. Boats and dog team were popular among Inuit of Greenland. Marine infrastructure of Alaska is represented by seaports. About $95 \%$ of all products is transported through port Anchorage (Alaska's State, 2013). Seaport Valdez, being the major oil port in the south coast of Alaska, is the terminal point of Trans-Alaska Pipeline. In Yukon sea transport is used for domestics operations and transporting fuels and lubricants.

The air freight is getting more popular, making $10 \%$ of the total land freight. Apart from consumer goods the oil and gas equipment is transported by air to oil fields. The helicopters are used for unloading while aircrafts are used for ice patrol. There is pipeline transport in gas and oil regions of Alaska and Northern Canada. Trans-Alaska Pipeline is the most outstanding constructions. The construction had been finished by 1977. The pipeline starts in Prudhoe Bay and conveys oil to Valdez, Alaska. The part, referred to in Alaska, makes up 1288 $\mathrm{km}$ in length.

In Kamchatka sea transport, air transport, motor transport are developed. There is a seaport in Krai center, thirteen terminals in the coast, an international airport, and twelve domestic operations airfields, three heliports, $3043 \mathrm{~km}$ of motor road, $38 \mathrm{~km}$ of federal motor road (Summary, 2014).

\subsection{The Comparative Assessments of Demographic Rates}

Kamchatka Krai and Iceland resemble regarding population rate. Kamchatka Krai's population is seventeen times less than Hokkaido's population, and two times less Alaska's population, but considerably larger than population of Northern Canada, Greenland and Spitsbergen. There is the uneven distribution of population in the regions considered. It depends on climatic conditions and urbanization. Thus, $90 \%$ of inhabitants of Greenland ("Black Angel", 2014) live along the south-western coast, and $90 \%$ of population of Northern Canada lives along the USA border (Tourism. North America, 2014). However, there is also uneven distribution of population. The distribution of population in Spitsbergen depends on agricultural and research activities of the contracting states. Majority lives in Norwegian camps, minority lives in Russian ones. After the dissolution of the Soviet Union the number of the Russian people has decreased, while the number of the Norwegian people has increased in Spitsbergen (Population of Svalbard, 2014). There is an urban population growth as mining and manufacturing industries are being developed. There is $24 \%$ of rural population and $76 \%$ of urban population in Hokkaido, specializing on farm produce (2011 г.) (Statistics Bureau Ministry, 2011). 
The regions studied are characterized by low population density.

The regions resemble regarding the indicator of age population. There is middle-aged population in the Kamchatka Krai, Greenland, Iceland, Alaska, Yukon, and North West Canada and on the Aleutian Islands. There is 37 aged-population in Kamchatka Krai and Iceland. The youngest population $(24,8)$ is in Nunavut (Estimates of population, Canada, 2014). At the same time the total fertility rate in Kamchatka Krai, Hokkaido, Yukon, North West Canada does not ensure simple reproduction of the population. The total fertility rate corresponds to a simple reproduction in Greenland, Iceland, Alaska and extended reproduction in Nunavut. Life expectancy in Kamchatka $(72,29)$ was higher than in Greenland $(71)$ in 2012. However, it depends on a gender. In Greenland male population is higher than female population by $5,6 \%$, which is opposite in the modern world as a whole.

The intense migration takes place in these regions. The adverse climatic conditions and industrial employment structure influence the migration. Organising new productions and developing old ones lead to both local and foreign specialists influx, which partly compensates outflow of locals. Thus, a great outflow of population from Northern Canada was partly compensated by labour migration in 2013. In the period considered Kamchatka Krai, Greenland, Iceland, North West Canada and Nunavut had a negative total migration balance, while Hokkaido, Alaska and Yukon had a positive one (Alaska Population Overview, 2010). As natural increase and migration predetermine population rate changing, they can compensate each other, acting in different ways. In 2013 in Kamchatka there was a negative migration balance, but due to the positive natural population increase, there was no population loss. The migration covered the negative natural population increase in Hokkaido in 2010. The regions differ in ethnic groups. Urbanization negatively influences the local people, destroying traditions and lifestyle and bringing the issue of marginalization.

\subsection{The Comparative Assessments of Fiscal Policy and Financial System}

The fiscal policy is controlled by the government agencies in Iceland, as in every northwestern economies. Apart from the traditional reinforcement sources of the state budget - taxes, custom duties and so on, the Icelandic state gets considerable incomes from the created infrastructure in the country, these are post, telephone services, shipping, as well as a number of monopolies, including the monopoly on a sale of strong drinks and tobacco goods. Budget of Iceland has always been characterized by social orientation. There were special programs among new ones, directed to the reduction of youth unemployment and household debt during the post-crisis period from 2010 to 2012. Direct foreign investments play an important role in the economy of Iceland and are aimed at the construction of power-consuming industries, the creation of tourism infrastructure and the development of agriculture.

The specificity of the fiscal system in Greenland is that the main revenue side of the budget is developed in the form of governmental grants from the budget of Denmark. Denmark invests in almost all its social programs. Social policy in Greenland is directed to the maintenance of public health and educational systems. The expenditure budget of Greenland, as well as of Iceland, is characterized by high level of social expenditures, whose share was about $26 \%$ in 2012.

Northern Canada is more dependent on federal transfers than the provinces. Thus, Yukon's revenues make up only $10-20 \%$ of the total income. The special transfer regime Territorial Formula Financing has been worked out for Northern Canada. The budgets of Northern Canada are characterized by a significant proportion of special purpose funding, primarily, Canada Health and Social Transfer - CHST and Federal Transfers and Deductions Health Canada. The rate of income tax on individuals in Northern Canada is lower than in the whole country and is determined by the level of territory development. Tax deductions such as charge-off for travelling to the place of leave and place of treatment are widely used in Northern Canada. The main flow of foreign investments in Northern Canada goes to the extractive industries sector.

The peculiarity of financial system in Alaska is associated with the USA Federal Organization that provides the states with a great power in lawmaking. According to Tax Foundation data, the Alaskans are paid about 1,87 dollars of federal funds on every dollar of taxes. Today Alaska is ranked number two in the country due to this index, it took fourteenth place in 1992. To create favorable living conditions, the USA government and Alaska authorities realize socially oriented public policy in the northern state, based on the profit redistribution accrued by the owners of basic, raw material industries and economic diversification in the country. Alaska is one of the US states during the last two decades, where individual income tax is one of the lowest in the country. In order to preserve financial stability in Alaska, the funds such as Alaska Permanent Fund and Constitutional Budget Reserve Fund are established. The main aim of the Alaska Permanent Fund is to establish investment base that could provide the further generations with incomes, when oil resources will be run out. 
Thus, the government supports the northern peoples in the northern European countries, North American and Japan, making up the inhabitation in severe weather conditions through social benefits and guarantees. Moreover, the indigenous peoples of the North support programs are extensively realized in Canada and in the USA. Hokkaido, as whole Japan, has negative demography despite the high life expectancy. There is high child mortality, negative migration balance and low social state support in Kamchatka Krai.

\section{The Discussions}

Comparative analysis of the sectoral structure has revealed the existence of the advantage in the development of Kamchatka Krai in comparison with other regions, namely, production diversification. Despite the fact that fisheries are the main branch, the development of other industries is also important. However, the territory should increase the production with higher added value. The service industry, having the higher share, is represented weaker in Kamchatka Krai in comparison with other regions. Due to the best production diversification, the impact of the external threats becomes weaker.

Provision and arrangement of the infrastructure is a major challenge in the northern territories, because these territories are developing as primary ones. Iceland is particularly advanced, in terms of energy. There is also developed transport infrastructure. There is developed transport and energy infrastructure in Japan, due to the nuclear power plants closure it needs to recovery energy resources. The transport infrastructure has been established in Kamchatka Krai, but it has been exhausted and many projects are to be fully repaired. However, considering Kamchatka Krai as an important transport nodal point of the Northern Sea Route, the exigency occurs, either in the railway construction, or in the road infrastructure improvement. The same problem takes place in the development of the regional power-generating sector.

Successful development of these countries is explained by government support, official guarantee and provision of such benefits as education, health care, taxes and export. All these conditions allow the territories to be developed successfully and involve into investment and human resources.

\section{Conclusions}

Thus, any region has a unique combination of social and economic potential, national and cultural peculiarities, historical traditions, as well as natural resource and geography and economic development conditions. The detailed analysis of the social and economic phenomena and reconstruction of the existing relationships between them give an opportunity to identify the nature of the ongoing processes considering the features and developing conditions of particular regions. This makes it possible to raise quality level of corporate planning and explains priority guidelines of investments and human resources mobilization, significantly increasing the effectiveness of regional development policies.

The comparative analysis method is supposed to be very perspective and useful to assess the directions of regional development in future studies. The instruments of state regulation are typical both in Russia and in other countries.

The comparative analysis of the regions that have the same geographical, geological, climatic and other relevant features makes it possible to formulate the recommendations for solving development problems of Kamchatka Krai considering the experiences of the analyzed northern regions such as Hokkaido, Greenland, Iceland, Spitsbergen, Alaska, the Aleutian Islands and Northern Canada.

The comparative analysis of social and economic development of regions with similar geographical, geological and climatic conditions made it possible to define effective instruments, factors and resources able to provide dynamic development of region economies. The analysis of state regulation instruments provides a deeper understanding of the role of the state regulation in the enhancing the effectiveness of regional development.

\section{Acknowledgement}

The study was conducted in the framework of research "Socio-economic factors and innovative mechanisms for implementation of the policy of dynamic development of the Far East" (research project of Ministry of Education and Science of Russian Federation № 2014/292).

\section{References}

"Black Angel" restart in Greenland. (2014). Metal Supply and Sales. Retrieved from http://www.metalinfo.ru/ $\mathrm{ru} / \mathrm{news} / 28900$

Agranat, G. A. (2003). Alyaska - the new model of development. EKO. Russian economic journal, 6, 36-60.

Alaska Permanent Fund Corporation Annual Report 2013. Retrieved from http://www.apfc.org/_amiReports 
Archive/FY2013AnnualReport.pdf

Alaska Population Overview, 2010 Census and 2011 Estimates. Department of Labor and Workforce Development. Retrieved from http://laborstats.alaska.gov/pop/estimates/pub/1011popover.pdf .

Alaska's State and Local Tax Burden. Retrieved from http://taxfoundation.org/article/annual-state-local-taxburden-ranking-fy-2011

American Century Aluminum buys primary aluminum plant in Iceland. (2014). Information Analysis Centre Mineral. Retrieved from http://www.mineral.ru

Belikovich, A.V. (1995). Arctic: land and people. Proceedings of the Research Center "Chukotka" (p. 128).

Bone, R. (1992). The Geography of the Canadian North. Issues and Challenges (p. 284). Toronto, Oxford University Press.

EcoENERGY for Aboriginal and Northern Communities Program Results 2007-2011. Aboriginal Affairs and Northern Development Canada. Retrieved from http://www.aadnc-aandc.gc.ca/eng/1314215496845/ 1314215722851

Enterprises Iceland. (2014). Retrieved from http://smotret-mir.ru/islandiya/predpriyatiya-islandii.html

Estimates of population, Canada, provinces and territories. Statistics Canada. Retrieved from http://www.statcan.gc.ca/tables-tableaux/sum-som/101/cst01/demo04a-eng.htm

Grandmont, K., Cardille, J. A., Fortier, D., \& Gibryen, T. (2012). Assessing land suitability for residential development in permafrost regions: A multi-criteria approach to land-use planning in northern Quebec, Canada. Journal of Environmental Assessment Policy and Management, 14(1), Article number 1250003.

Gross Domestic Product (GDP) by Industry at Basic Prices 2012. Yucon Covernment. Retrieved from http://www.eco.gov. yk.ca/fr/pdf/gdp_2012.pdf

Health expenditure, total (\% of GDP). Retrieved from http://data.worldbank.org/indicator/ SH.XPD.TOTL.ZS

Hokkaido. Encyclopedia of Japan from A to Z. (2009). EdwART. Retrieved from http://dic.academic.ru/dic.nsf/ enc_japan $/ 983 / \% \mathrm{D} 0 \% \mathrm{~A} 5 \% \mathrm{D} 0 \% \mathrm{BE} \% \mathrm{D} 0 \% \mathrm{BA} \% \mathrm{D} 0 \% \mathrm{BA} \% \mathrm{D} 0 \% \mathrm{~B} 0 \% \mathrm{D} 0 \% \mathrm{~B} 9 \% \mathrm{D} 0 \% \mathrm{~B} 4 \% \mathrm{D} 0 \% \mathrm{BE}$

Iceland's economy: industry, agriculture, transportation, finance. (2014). Retrieved from http://www.gecont.ru/articles/econ/island.htm

Japan - Geographic essay. (2014). Retrieved from http://scansbook.ru/page,55,1304-yaponiya-geograficheskijocherk.html

Kharevskiy, A. A. (2001). Arctic policy in Canada: Transformation approach to Northern Management. Proceedings of the Komi Scientific Center, Ural Branch of RAS, 2(6), 97-102.

Kozlova, O.A., \& Karmakulova, A.V. (2013). Problems and prospects of the flexible employment forms' development in the northern region. Economy of Region, 2, 27-34.

Lonak - See world ports. Retrieved from http://logistics.lonak.com/ru/ports

METI - Ministry of Economy, Trade and Industry. Research and Statistics Department Economic and Industrial Policy Bureau "2005 Inter-Regional Input-Output Table." Retrieved from http://www.meti.go.jp/english/ statistics/tyo/tiikiio/pdf/2005report.pdf.

Population of Svalbard. Statistic Norway. Retrieved from http://www.ssb.no/en/befolkning/statistikker/ befsvalbard/halvaar

Pullman, E. R., Jorgenson, M. T., \& Shur, Y. (2007). Thaw settlement in soils of the Arctic Coastal Plain, Alaska. Arctic, Antarctic, and Alpine Research, 39(3), 468-476. doi: 10.1657/1523-0430(05-045)

Scheel, H. H. (2012). This is Svalbard. What the figures say. Statistics Norway. Retrieved from http://www.ssb.no/en/befolkning/artikler-og-publikasjoner/_attachment/ 91885?_ts=13c71434ac8 50\%

Socio-economic status of Kamchatka Territory. (2012). Retrieved from http://www.kamchatka.gov.ru/index.php? cont $=$ newlibcont $\&$ menu $=12 \&$ menu $2=205 \& \mathrm{id}=47$

Statistics Bureau Ministry of Internal Affaire and Communications. Retrieved from http://www.stat.go.jp/ english/data/nenkan/back62/1431-02.htm

Statistics Greenland. (2014). Retrieved from http://www.stat.gl/default.asp?lang=en 
Summary of the Kamchatka region. (2014). Ministry of the Russian Federation on the development of the Far East. Retrieved from http://minvostokrazvitia.ru/ regions/reg41.php

The Mining Industry and the Social Stakes of Development in the Arctic. (2014). Retrieved from http://nwt-tno.inac-ainc.gc.ca/cds_e.htm\#3

The structure of the gross regional product of the Kamchatka Territory for 2011. United interagency information-statistical system. Retrieved from http://www.fedstat.ru/ indicator/data.do?id=43890

Tourism. North America. (2014). Retrieved from http://ks.kg/severnajaamerika/kanada/159-dlya-kanadyharakterna-kraynyaya-neravnomernost-razmescheniya-naseleniya.html.

U.S. Economic Accounts. Bureau of Economic Analysis. Retrieved from http://www.bea.gov/index.htm.

Vereshchagina, V. B. (2011). Indicators of sustainable development of the regions of offshore oil-and-gas production in the Northern Seas. Bulletin of St. Petersburg State University. Series Geology and Geography, 7, 107-113.

Vozgrin, V. Ye. (1984). Greenland and the Greenlanders (p. 157). Moscow, Mysl.

\section{Copyrights}

Copyright for this article is retained by the author(s), with first publication rights granted to the journal.

This is an open-access article distributed under the terms and conditions of the Creative Commons Attribution license (http://creativecommons.org/licenses/by/3.0/). 